\title{
Effects of methanolic extract of yohimbe bark (Pausinystalia yohimbe) on isolated rabbit aortic strip and rat uterus
}

\author{
Hozeifa Mohamed Hassan ${ }^{1^{\star}}$, Imad Mohamed Taj Eldin ${ }^{1}$, Elhadi Mohamed Ahmed ${ }^{2}$, \\ Abd Elwahab Hassan Mohamed ${ }^{3}$, Nizar Sirag ${ }^{2}$ \\ ${ }^{1}$ Department of Pharmacology, Faculty of Pharmacy, University of Gezira, Wad Medani, Sudan; \\ *Corresponding Author: hozhooz@hotmail.com \\ ${ }^{2}$ Department of Pharmacognosy, Faculty of Pharmacy, University of Gezira, Wad Medani, Sudan \\ ${ }^{3}$ Department of Pharmacology and Toxicology, Medicinal and Aromatic Plant Research Institute, National Centre of Research, \\ Khartoum, Sudan
}

Received 12 March 2013; revised 15 April 2013; accepted 1 May 2013

Copyright (C) 2013 Hozeifa Mohamed Hassan et al. This is an open access article distributed under the Creative Commons Attribution License, which permits unrestricted use, distribution, and reproduction in any medium, provided the original work is properly cited.

\section{ABSTRACT}

Background: Medicinal plants contain physiologically active principles that over the years have been exploited in traditional medicine for the treatment of various ailments. Objectives and Methods: This study aimed to investigate the effects of the methanolic extract of Pausinystalia yohimbe bark $(5 \mathrm{mg} / \mathrm{ml})$ on isolated rabbit aortic strip and rat uterus. Results: methanolic extract of $P$. yohimbe bark $(5 \mathrm{mg} / \mathrm{ml})$ produced relaxation of the phenylephrine precontracted-rabbit aortic strip. This relaxation may be resulted through nitric oxide (NO), since the pretreatment of the isolated rabbit aortic strip with methylene blue inhibited the NO-mediated relaxation. Moreover, the extract exhibited relaxation of rat uterine muscles, which appeared to be not mediated by activation of $\beta_{2}$-adrenoceptors and/or $H_{2}$ receptors, since the relaxant effect continued even after the pretreatment of the tissue with propranolol and ranitidine respectively. Conclusion: The obtained results revealed that methanolic extract of $P$. yohimbe bark caused relaxation of both isolated rat uterus and rabbit aortic strip through facilitating the role of endogenous compounds such as NO.

Keywords: P. yohimbe Bark; Isolated Tissues; Aortic Strip; Rat Uterus; Relaxation; Nitric Oxide

\section{INTRODUCTION}

Medicinal plants have played a key role in the world health care with about $80 \%$ of Africans depending on phytomedicine, which has shown a wide range of uses in the treatment of diseases especially priority diseases of Africa such as malaria, sickle-cell anemia, diabetes and hypertension. The medicinal plants have more beneficial effects than their synthetic counterparts through being safer, acceptable, affordable, culturally compatible and suitable for chronic treatments. Some African phytomedicines are well known in the international market and so supply economic benefit for producing countries [1]. Pausinystalia yohimbe (family Rubiaceae) is a valuable tree native to the Gulf of Guinea and distributed in evergreen closed-canopy forests from Southern Nigeria to Congolese Mayombe, Gabon, possibly the Democratic Republic of Congo and Cameron [2-5]. The main active constituents of the bark are the indole alkaloids such as yohimbine and related compounds [6]. Yohimbine is considered a fairly selective $\alpha_{2}$-adrenoceptor antagonist (the $\alpha_{2}: \alpha_{1}$ selectivity ratio varying between 10 and 100 depending on the model used) [7-11].

This study aimed to investigate the effects of the methanolic extract of $P$. yohimbe bark on isolated rabbit aortic strip and rat uterus. The experimental protocol was ethically approved by the ethical committee at Faculty of Pharmacy, University of Gezira.

\section{MATERIALS AND METHODS}

\subsection{Materials}

\section{Plants Materials}

The dried chopped small pieces of $P$. yohimbe barks had been collected from South West Cameroon in May $25^{\text {th }}, 2008$. The plant material was authenticated by the 
Provincial Service for Forestry, Ministry of Forestry and Wildlife, Republic of Cameroon (Certificate No. 004/ $\mathrm{CO} / \mathrm{MINFOF} / \mathrm{PDFOF} / \mathrm{PSF} / \mathrm{SW} / 230$ ).

\subsection{Methods}

\subsubsection{Extraction of Plant Materials}

The coarsely powdered barks (500 grams) of $P$. yohimbe were extracted by maceration using pure methanol in a conical flask for 72 hours with intermittent shaking, filtered and evaporated by rotary evaporator at $60^{\circ} \mathrm{C}$. The dried extract powder was kept in an amber glass container in a refrigerator for the biological test.

\subsubsection{Rabbit Aortic Strip Preparation}

A rabbit of local strain $(1.75 \mathrm{~kg})$ was used in this experiment. The preparation was based on the method adopted by Furchgott and Bhadrakom (1953) [12]. The rabbit was killed by neck dislocation and exsanguination. The chest was opened, the internal viscera were pulled aside and the aorta had been exposed. The aorta was cut closed to the heart and dissected as far as possible. Then after, the tissue was transferred to a petri dish containing aerated Krebs solution. The aorta was located over a large plastic cannula, surrounding fats and connective tissues were removed, then the aorta was cut spirally by curved scissor to produce a continuous strip. Threads had been tied to each end of the strip and one end was attached to the tissue holder. The mounted tissue then was transferred to a $25 \mathrm{ml}$ organ bath filled with oxygenated Krebs solution maintained at $37^{\circ} \mathrm{C}$ and the top thread was attached to Harvard isometric transducer connected to Harvard Universal Oscillograph recorder (Harvard Apparatus Limited UK). The preparation was allowed to stand for 45 minutes, under $2 \mathrm{~g}$ resting tension before addition of the reference drugs (acetylcholine $250 \mathrm{ng} / \mathrm{ml}$, phenylephrine $12 \mu \mathrm{g} / \mathrm{ml}$ and $25 \mu \mathrm{g} / \mathrm{ml}$ methylene blue) and the $P$. yohimbe extract.

\subsubsection{Rat Uterus Preparation}

The preparation was based on the method of De Jalon et al., (1945) [13] and Kitchen, (1984) [14]. A female Albino rat weighing $170 \mathrm{~g}$ was selected; it was brought to the estrus state by administration of $17 \beta$-estradiol ( 2 $\mathrm{mg} / \mathrm{kg}$ ) subcutaneously 72 hours prior to the experiment). The rat was killed by slaughtering and exsanguination. The abdomen was opened, and the two uterine horns (pink colorations) had been exposed by pulling aside the intestine. Each horn was freed carefully from the surrounding fats and mesenteric attachments then each of them was cut out separately, and transferred to a petri dish containing De Jalon solution. A longitudinal cut was made to form a sheet of muscle instead of a tube. Threads had been passed through one wall of the uterus at both top and bottom, the bottom thread was attached to the tissue holder and transferred to a $50 \mathrm{ml}$ organ bath containing aerated De Jalon solution maintained at $32^{\circ} \mathrm{C}$ and the top thread was attached to Harvard isotonic transducer connected to Harvard Student Oscillograph recorder. The preparation was allowed to adapt for 30 minutes, under $0.5 \mathrm{~g}$ tension before addition of the reference drugs (acetylcholine $50 \mathrm{ng} / \mathrm{ml}$, adrenaline 100 $\mathrm{ng} / \mathrm{ml}$, atropine $100 \mathrm{ng} / \mathrm{ml}$, histamine $500 \mu \mathrm{g} / \mathrm{ml}$, ranitidine $1 \mathrm{mg} / \mathrm{ml}$ and propranolol $1 \mu \mathrm{g} / \mathrm{ml}$ ) and $P$. yohimbe extract.

\section{RESULTS}

The effects of phenylephrine, acetylcholine and methanolic extract of $P$. yohimbe on rabbit aortic strip were shown in Figures 1 and 2. The tissue was contracted by phenylephrine $(12 \mu \mathrm{g} / \mathrm{ml})$; and an ostensible relaxation was obtained by acetylcholine $(250 \mathrm{ng} / \mathrm{ml})$, which indicated the integrity of the endothelial cells.

The $P$. yohimbe extract (dose $5 \mathrm{mg} / \mathrm{ml}$ ) relaxed the contracted aortic strip to the normal baseline with maximal relaxation activity occurred after 1 minute. This relaxant effect of the extract was blocked by the pre-addition of methylene blue $(25 \mu \mathrm{g} / \mathrm{ml})$.

Figures 3 and $\mathbf{4}$ demonstrate the effects of methanolic extract of $P$. yohimbe bark on uterus taken from 72 hours estradiol-treated female Albino rat $[13,14]$. Treatment

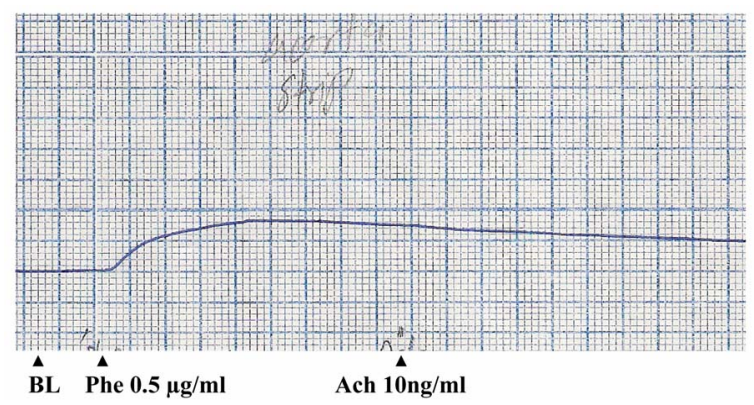

Figure 1. Effects of phenylephrine (Phe) and acetylcholine (Ach) on isolated rabbit aortic strip (BL: base line).
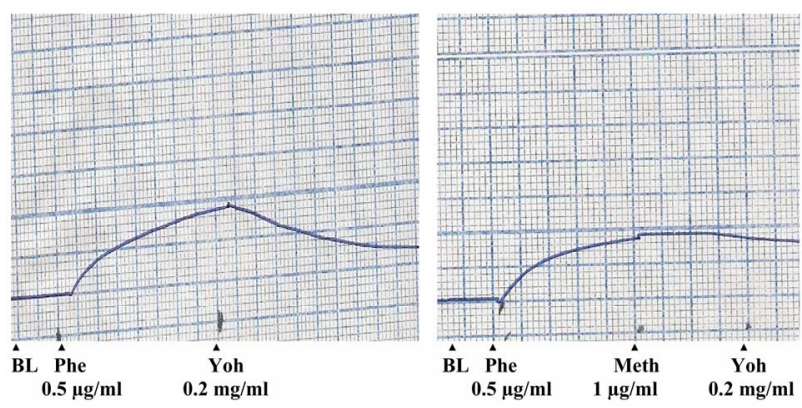

Figure 2. Effects of pheylephrine (Phe), methylene blue (Meth) and $P$. yohimbe extract (Yoh) on isolated rabbit aortic strip (BL: base line). 


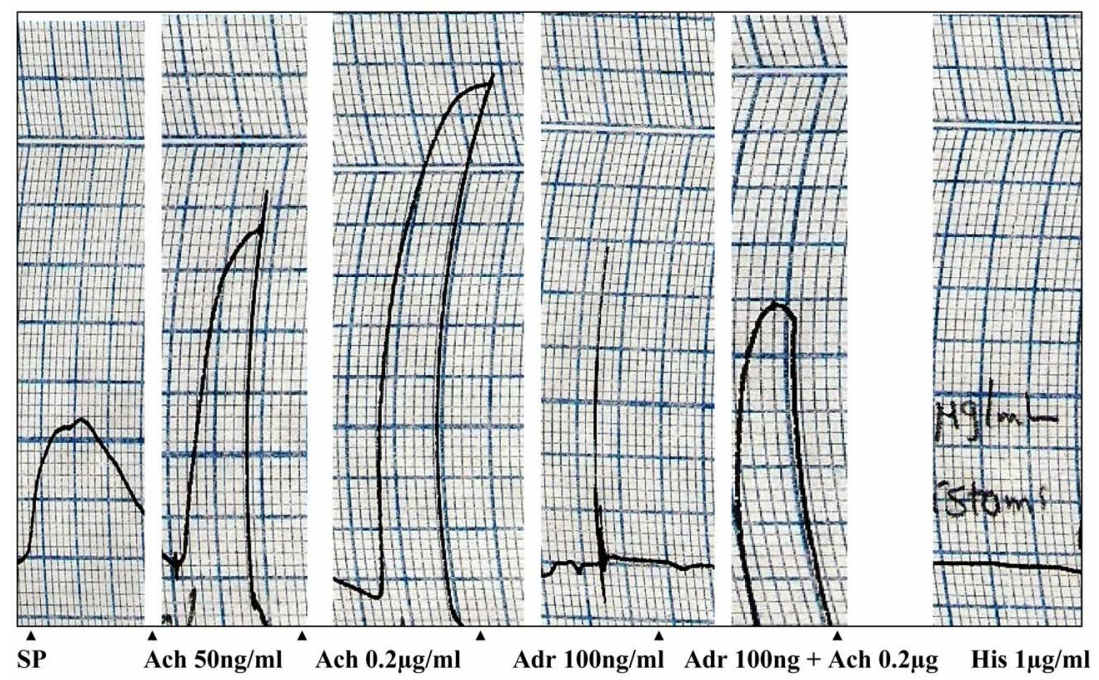

Figure 3. Effects of acetylcholine (Ach), adrenaline (Adr) and histamine (His) on isolated rat uterus (SP: spontaneous contractions).

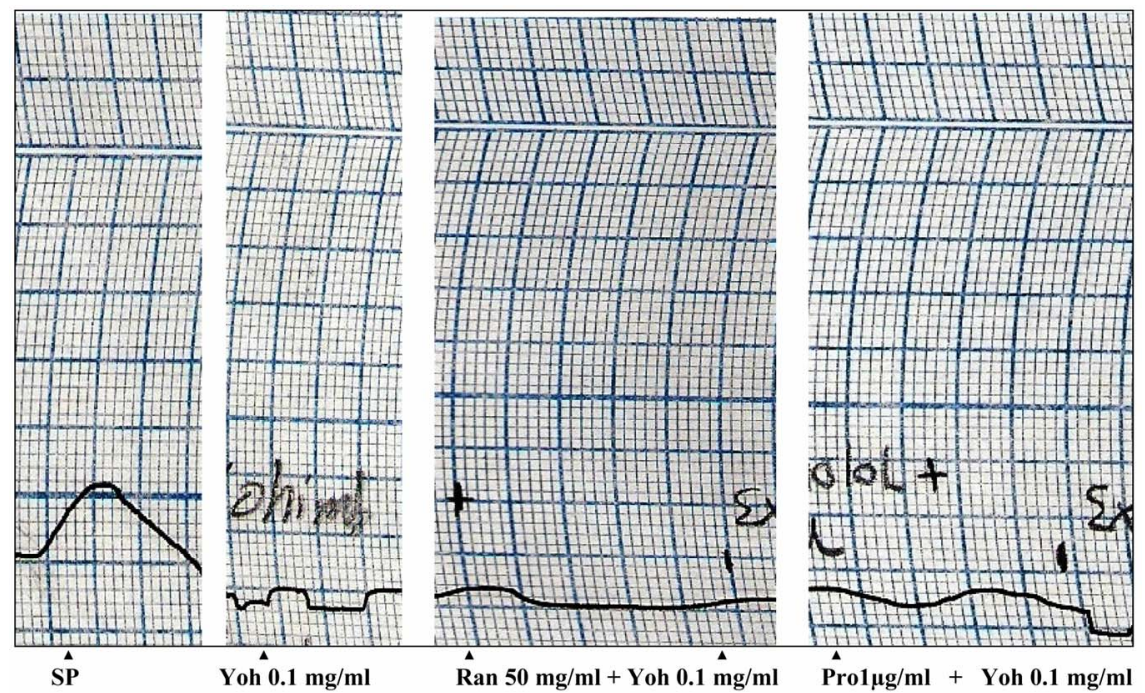

Figure 4. Effects of $P$. yohimbe extract (Yoh), ranitidine (Ran) and propranolol (Pro) on isolated rat uterus (SP: spontaneous contractions).

with estradiol (2 $\mathrm{mg} / \mathrm{kg}$ subcutaneously) increased the sensitivity of uterine muscle towards the action of the tested drugs (acetylcholine $50 \mathrm{ng} / \mathrm{ml}$, adrenaline 100 $\mathrm{ng} / \mathrm{ml}$, histamine $1 \mu \mathrm{g} / \mathrm{ml}$ and $P$. yohimbe extract 5 $\mathrm{mg} / \mathrm{ml})$. The isolated rat uterus was tested first by these drugs. Acetylcholine produced a dose-dependent contraction with a maximal contraction occurred by a dose of $0.2 \mu \mathrm{g} / \mathrm{ml}$ and this contraction was reduced by prior addition of adrenaline. Adrenaline and histamine showed a relaxant effect on the isolated uterus. When $P$. yohimbe $(5 \mathrm{mg} / \mathrm{ml})$ was tested on the uterus, it elicited a rapid relaxant activity which was attained in less than 1 minute. This inhibitory effect of the P. yohimbe extract was sustained and did not blocked, even after pre-treatment of the tissue with the histamine $\mathrm{H}_{2}$-receptors antagonist ranitidine $(1 \mathrm{mg} / \mathrm{ml})$ and the $\beta$-blocker propranolol (1 $\mu \mathrm{g} / \mathrm{ml})$.

\section{DISCUSSION}

These results indicated that, phenylephrine $\left(\alpha_{1}\right.$-adrenoceptors agonist) produced slow sustained contraction of the isolated aortic smooth muscle. It has been established that $\alpha_{1}$-adrenergic agonists in vascular smooth muscle increase calcium influx via the slow-inward current. Thus they enhance the degree of contraction of blood vessels [15-18].

Contraction or force development by smooth muscle cells depends upon the elevation of intracellular calcium in the myoplasm. This is caused by either release of in- 
tracellular calcium from the storage sites like mitochondria, or entry of calcium via voltage-operated calcium channels, or entry of calcium via receptor-operated channels $[15,18,19]$.

On the other hand, acetylcholine caused relaxation to the contracted tissue; this effect indicated the presence of intact endothelial cells. This endothelial-dependent response is principally regulated by release of nitric oxide (NO) from the endothelium which is synthesized from the amino acid L-arginine by endothelial nitric oxide synthase (eNOS) [20]. Acetylcholine (Ach) produces dilation of essentially all vascular beds, which is primarily due to stimulation of muscarinic receptors $\left(\mathrm{M}_{3}\right)$ that activates the $\mathrm{G}$ protein-phospholipase $\mathrm{C}$-inositol triphosphate $\left(\mathrm{G}_{\mathrm{q}}-\mathrm{PLC}-\mathrm{IP}_{3}\right)$ pathway and mobilizes cell calcium. In endothelial cells, this leads to $\mathrm{Ca}^{2+}$-calmodulindependent activation of eNOS and production of $\mathrm{NO}$ which diffuses to adjacent smooth muscle cells, where it stimulates the soluble guanylyl cyclase and causes relaxation [5,21,22].

Methanolic extract of $P$. yohimbe bark produced relaxation of the contracted aortic strip which was probably may be resulted through NO, since pretreatment of the isolated rabbit aortic strip with methylene blue (a soluble guanylyl cyclase inhibitor) inhibited the NOmediated relaxation of smooth muscle cells which was produced in the absence of methylene blue [23-25].

These findings match with previous studies on the effects of yohimbine on vascular smooth muscles. Ikunobu et al., (1990) [17] found that, yohimbine inhibited the blood vessels responses to adrenaline and phenylephrine. Moreover, yohimbine was found not significantly different than prazosin (a selective $\alpha_{1}$ adrenoceptor antagonist) in inhibiting the effects of phenylephrine and noradrenaline on rat aortic strips [26].

It was reported that, the use of acetylcholine resulted in uterine smooth muscle contractions through stimulation of muscarinic receptors $\left(\mathrm{M}_{3}\right)$, while adrenaline caused relaxation by stimulating $\beta_{2}$-adrenoceptors in the uterus [21].

On the other hand, histamine produced relaxation on the uterus, although it causes contractions in the other smooth muscles. Some investigators suggested that histamine-induced uterine relaxation is associated with activation of the histamine $\mathrm{H}_{2}$-receptors [27-30].

The methanolic extract of $P$. yohimbe bark produced relaxation of the uterine muscles, which appeared to be not mediated through activation of $\beta_{2}$-adrenoceptors because the relaxant effect continued even after the pretreatment of the tissue with propranolol (a non-selective $\beta$-adrenergic blocker). Also it was not mediated through activation of $\mathrm{H}_{2}$ receptors because the relaxation persisted after the prior addition of ranitidine, a selective $\mathrm{H}_{2}$ receptors antagonist.

\section{CONCLUSION}

As experimentally evident, it could be concluded that, methanolic extract of $P$. yohimbe bark caused relaxation on both isolated rat uterus and rabbit aortic strip, which may be directly by releasing relaxing substances such as nitric oxide $(\mathrm{NO})$.

\section{REFERENCES}

[1] Okigbo, R.N. and Mmeka, E.C. (2006) An appraisal of phytomedicine in Africa. King Mongkut's Institute of Technology Ladkrabang Science and Technology Journal, 6, 83-94.

[2] Clark, L.E. and Sunderland, T.C.H. (2004) The key nontimber forest products of Central Africa: State of knowledge. Sustainable Development Publication Series, 122, 121-140.

[3] Tchoundjeu, Z., Ngo Mpeck, M.L., Asaah, E. and Amougou, A. (2004) The role of vegetative propagation in the domestication of Pausinystalia johimbe (K. Schum), a highly threatened medicinal species of West and Central Africa. Forest Ecology and Management, 188, 175-183. doi:10.1016/j.foreco.2003.07.010

[4] Khosravi, M., Oryan, S., Haeri Rohani, S.A., Parivar, K. and Marandi, R. (2006) Control of environmental health and removal of rats by $\alpha_{2}$-adrenergic antagonists and potassium channel blocker. Iranian Journal of Environmental Health Science and Engineering, 3, 255-260.

[5] Brunton, L., Keith, P., Donald, B. and Iain, B. (2008) Goodman and Gilman's manual of pharmacology and therapeutics. Drugs acting at synaptic and neuroeffector junctional sites. 11th Edition, McGraw-Hill Medical Publishing Division, New York.

[6] Zanolari, B. (2003) Natural aphrodisiacs. Studies of commercially-available herbal recipes, and phytochemical investigation of Erythroxylum Vacciniifolium Mart. (Erythroxylaceae) from Brazil. Ph.D. Thesis, University of Lausanne, Lausanne.

[7] Goldberg, M.R. and Robertson, D. (1983) Yohimbine: A pharmacological probe for study of the $\alpha_{2}$-adrenoceptor. Pharmacology Review, 35, 143-180.

[8] Steers, W.D., McConnell, J. and Benson, G.S. (1984) Some pharmacologic effects of yohimbine on human and rabbit penis. Journal of Urology, 84, 799-802.

[9] Murburg, M.M., Villacres, E.C., Ko, G.N. and Veith, R.C. (1991) Effects of yohimbine on human sympathetic nervous system function. Journal of Clinical Endocrinology and Metabolism, 73, 861-865. doi:10.1210/jcem-73-4-861

[10] Aantaa, R. (2000) Alpha 2 -adrenoceptor antagonists. Baillière's Clinical Anesthesiology, 14, 285-292.

[11] Morales, A. (2000) Yohimbine in erectile dysfunction: The facts. International Journal of Impotence Research, 12, S70-S74. doi:10.1038/sj.ijir.3900508

[12] Furchgott, R.F. and Bhadrakom, S. (1953) Reactions of strips of rabbit aorta to epinephrine, isopropylarterenol, 
sodium nitrate and other drugs. Journal of Pharmacology and Experimental Therapeutics, 108, 129-143.

[13] De Jalon, P.G., Bayo, J.B. and De Jalon, M.G. (1945) Rat uterus preparation. Farmacoterapia Acta, 2, 313.

[14] Kitchen, I. (1984) Textbook of in vitro practical pharmacology. Blackwell Scientific Publication, Oxford.

[15] Bolton, T.B. (1979) Mechanism of action of transmitters and other substances on smooth muscle. Physiology Review, 59, 606-718.

[16] Dacquet, C., Mirranneu, C. and Mirranneu, J. (1987) Effects of calcium entry blockers on calcium dependent contraction of rat portal vein. British Journal of Pharmacology, 92, 203-211. doi:10.1111/j.1476-5381.1987.tb11313.x

[17] Ikunobu, M., Tsuyoshi, O., Shigeru, K., Shigeki, H. and Masafumi, O. (1990) Pharmacological sub-classification of $\alpha_{1}$-adrenoceptors in vascular smooth muscle. British Journal of Pharmacology, 99, 197-201. doi:10.1111/j.1476-5381.1990.tb14678.x

[18] Bhatti, A.S.A. and Khan, A.H. (2008) Re-evaluation of the effects of NSAIDS on blood vessels. Annals, 14, 3037.

[19] Marriot, J.F. (1988) A comparison of the effects of the calcium entry blockers verapamil, diltiazem and flunarizine against contractions of the rat isolated aorta and portal vein. British Journal of Pharmacology, 95, 145-154. doi:10.1111/j.1476-5381.1988.tb16558.x

[20] Janssens, S.P., Shimouchi, A. and Quertermous, T. (1992) Cloning and expression of a cDNA encoding human endothelium-derived relaxing factor/nitric oxide synthase. Journal of Biological Chemistry, 267, 14519.

[21] Katzung, G.B. (2001) Basic and clinical pharmacology. adrenoceptor antagonist drugs. 8th edition, McGraw-Hill, Philadelphia.

[22] Finkel, R., Richard, C., Michelle, A. and Cubeddu, L.X.
(2009) Lippincott's illustrated reviews: Pharmacology. Drugs affecting the autonomic nervous system. 4th Edition, Lippincott Williams and Wilkins, Philadelphia.

[23] Dasan, L., Sheela, D. and Steven, R.V. (1995) Effects of methylene blue and LY83583 on neuronal nitric oxide synthase and NADPH-diaphorase. European Journal of Pharmacology Section, 290, 247-251. doi:10.1016/0922-4106(95)00084-4

[24] Toda, N., Kazuhede, A. and Tomio, O. (2005) Nitric oxide and penile erectile function. Pharmacology and Therapeutics, 106, 233-266. doi:10.1016/j.pharmthera.2004.11.011

[25] Hozeifa, M.H., Imad, M.T., Elhadi, M.M., Abd Elwahab, H.M. and Nizar, S. (2012) Effects of methanolic extract of Pausinystalia yohimbe bark on blood glucose level in normal fasting rats. Journal of Health, 4, 1225-1228. doi: $10.4236 /$ health.2012.412180

[26] Digges, K.G. and Summers, R.J. (1983) Characterization of postsynaptic $\alpha$-adrenoceptors in rat aortic strips and portal veins. British Journal of Pharmacology, 79, 655665. doi:10.1111/j.1476-5381.1983.tb10002.x

[27] Jensen, K.B. and Vennerod, A.M. (1961) Reversal of the inhibitory action of adrenaline and histamine on rat uterus. Acta Pharmacologica et Toxicologica, 18, 307-312. doi:10.1111/j.1600-0773.1961.tb01672.x

[28] Tozzi, S. (1973) The mechanisms of action of histamine on the isolated rat uterus. Journal of Pharmacology and Experimental Therapeutics, 187, 511-517.

[29] Bertaccini, G., Molina, E., Vitali, T. and Zappia, L. (1979) Actions of histamine receptor agonists and antagonists on the rat uterus. British Journal of Pharmacology, 66, 1317. doi:10.1111/j.1476-5381.1979.tb16091.x

[30] Rosić, M., Guozden, R., Zorica, L., Suzana, P. and Rajko, L. (2005) Effects of phenylethylamine on isolated uterus in rats treated with estrogen. Jugoslovenska Medicinska Biohemija, 24, 265-270. doi:10.2298/JMB0504265R 